\title{
Biography of Jack Holland (1926-2014): Chert expert
}

\author{
William Engelbrecht and Lisa Marie Anselmi
}

Anthropology Department, SUNY Buffalo State. 1300 Elmwood Ave., Buffalo, NY, 14222, U.S.A.

Email: Engelbrecht: engelbwe@gmail.com; Anselmi: anselmlm@buffalostate.edu

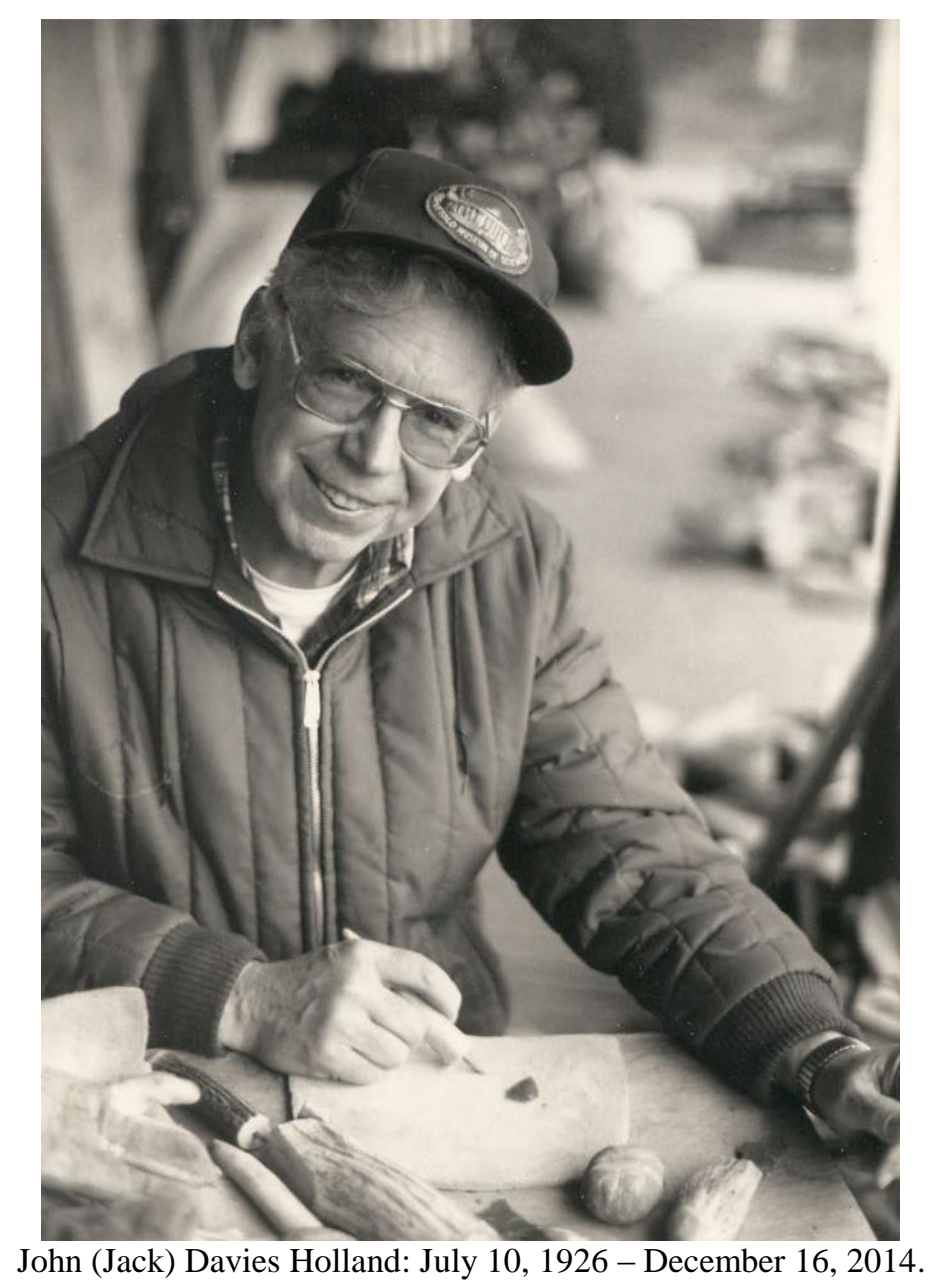

Jack was born and grew up in Lock Haven Pennsylvania, the son of William G. Holland and Florence (Davies) Holland. He had an older brother, William and a younger brother, Donald. Jack spent much of his boyhood roaming the surrounding flood plains of the West Branch of the Susquehanna River looking for arrowheads. As Jack recalled, his parents gave him a great deal of freedom, just asking that he be home in time for dinner. Dr. T. B. Stewart,

Published by the School of History, Classics and Archaeology, University of Edinburgh ISSN: 2055-0472. URL: http://journals.ed.ac.uk/lithicstudies/

This work is licensed under a Creative Commons Attribution 2.5 UK: Scotland License. 
a Lock Haven dentist, encouraged Jack's early archaeological interest, helping him to identify specimens. Dr. Stewart had an extensive archaeological collection and had worked with Donald Cadzow, Pennsylvania's State Archaeologist (1929-1939). Dr. Stewart was also one of the founders of the Society for Pennsylvania Archaeology, an organization with which Jack would later become involved and that bestowed their J. Alden Mason Award on him as a professional who encouraged society members in the "proper pursuit of archaeology."

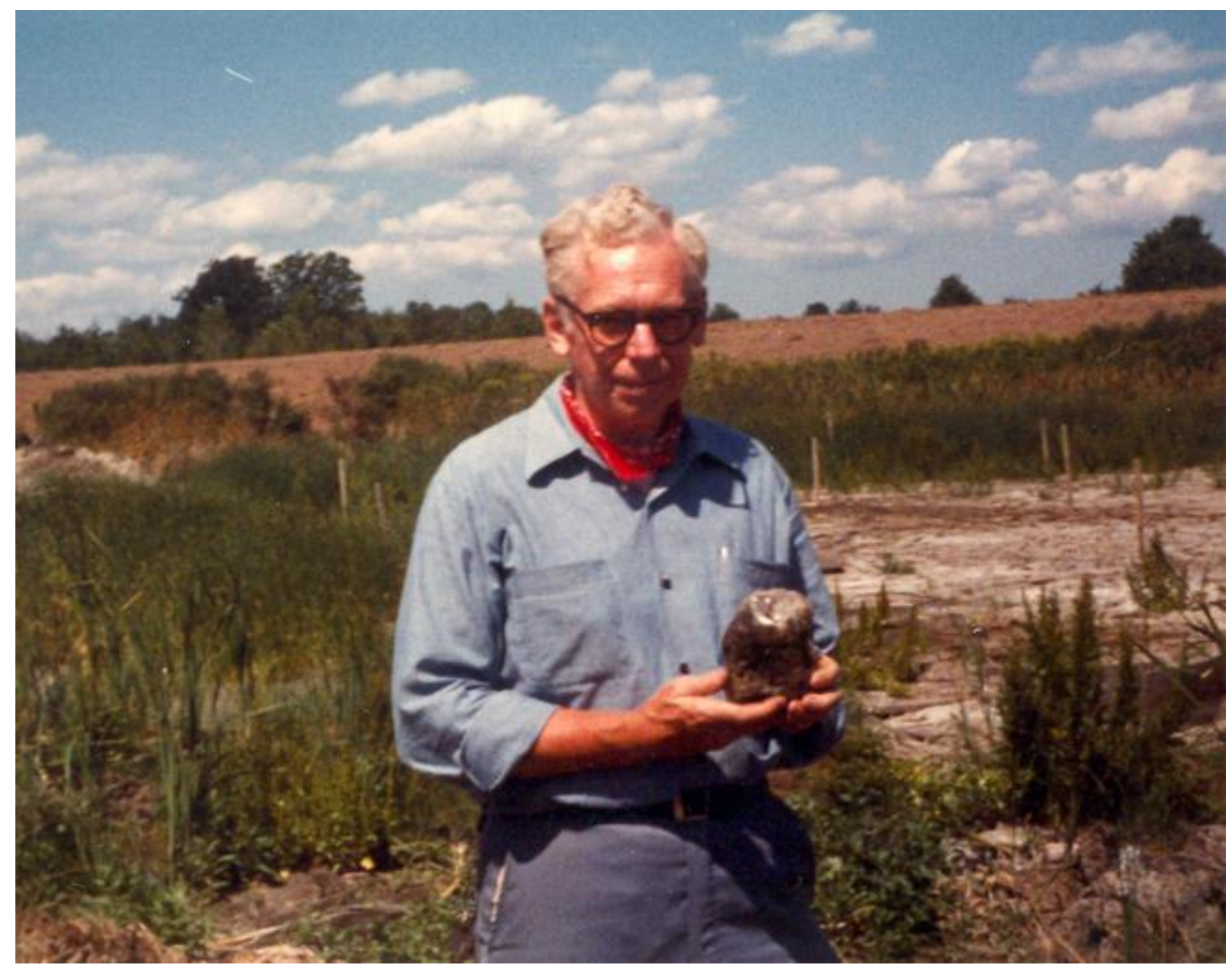

Figure 1. Jack Holland. (Photo by Jack Holland.)

Jack was an athlete in high school, participating in wrestling, track, and serving as captain of the Lock Haven football team. He met his future wife, Louise, in high school and they married in the summer of 1944 after graduating from high school. On July 29, 2014 they celebrated their 70th anniversary. Also in 1944 Jack turned 18 and was called up for the draft but failed the eye exam. With World War II continuing, Jack hitchhiked to Philadelphia where he joined the Merchant Marine, only to have an old football injury to the cartilage in his leg cause him to be discharged. However, due to a shortage of manpower, physical standards were lowered and Jack volunteered for the Army Air Corp in which he served for a year and a half as an electrical engineer.

Following World War II, Jack was hired as an electronics technician, first at Sylvania and then American Aniline, both in Lock Haven. During this time he took electrical industrial correspondence courses from Pennsylvania State University. In 1953 he went to work at the Ford Stamping Plant south of Buffalo, New York, working there for 32 years. At Ford he honed his analytic skills in fixing malfunctions in the huge electrical control panels. As he recalled, he also practiced what might be called social engineering, quietly approaching 
someone who might have sabotaged production to take a break by saying something like: "Why don't you flip that switch to see if that will start things up again." He also recalled being supportive of minority workers when they were hired. This supportive, nonconfrontational manner was to characterize his later involvement in the archaeological community.

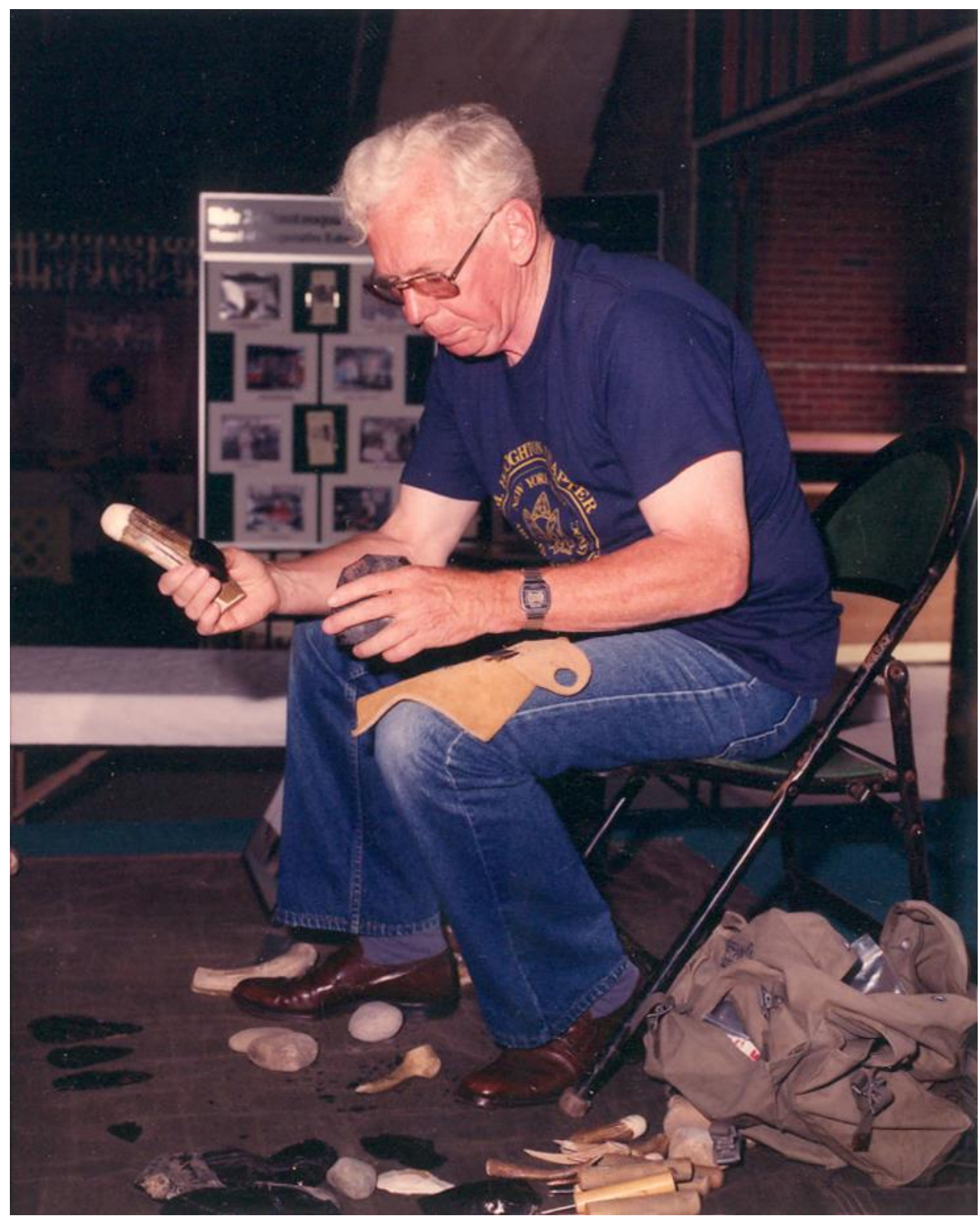

Figure 2. Jack Holland demonstrating knapping techniques. (Photo by Jack Holland.)

Jack became active in archaeology again in 1958 when Dr. Marian White, then associated with the Buffalo Museum of Science, began salvage excavations on the Kleis site in Hamburg, NY, located not far from his home in West Seneca. He volunteered on this and a number of subsequent projects with Marian White. When the Houghton Chapter (Buffalo Chapter) of the New York State Archaeological Association was established in 1961 by Marian White, Jack became one of the founding members.

In 1964 his archaeological volunteer work was put on hold when he took up black powder shooting with his son, winning numerous first place national championship awards and learning about gunflints and rifle parts in the process. Then in the early 1980's while still 
working at the Ford Stamping Plant, Jack entered Empire State College's individualized degree program in which students meet one on one with an instructor, having mutually agreed on a specific topic of study. The senior author was privileged to work with Jack on a number of contracts, but Jack was to soon surpass his instructor when it came to the study of stone tools. While a student at Empire State, Jack took a flint knapping course from D.C. Waldorf, followed by a course in stone tool manufacture from Frank Cowan at the Center for American Archaeology at Kampsville, Illinois. He then attended Errett Callahan's class in knapping at Glass Buttes, Oregon. On his own he devised a use wear experiment using 25 different types of chert, each type being used for the same duration for the same tasks. Presentation of the results garnered a state-wide award from Empire State College, from which he graduated in the summer of 1985, having retired from Ford that spring.

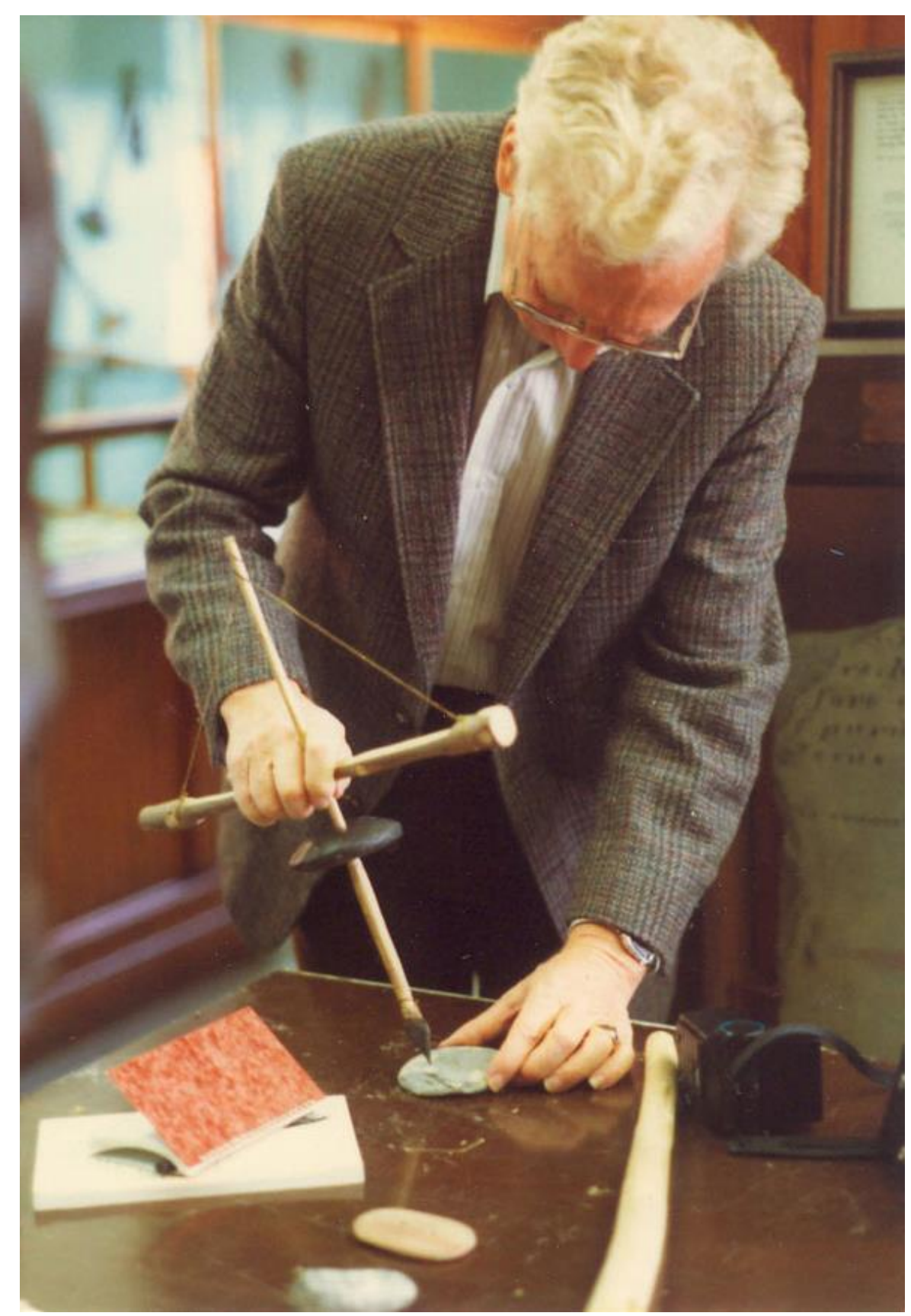

Figure 3. Jack Holland demonstrating a stone drill. (Photo by Jack Holland.) 
Starting in 1982, Jack began volunteering on archaeological projects with Dr. Mike Gramly, then at the Buffalo Museum of Science. He worked at the Potts site in New York, in Dover Tennessee, and at Fort Laurens in Ohio among many others. His skill at playing the harmonica around an evening campfire was always welcome and Jack made many friends both in the field and at archaeological meetings. Jack helped organize the first knapp-in at the Buffalo Museum of Science, bringing together D.C. Waldorf, Bruce Bradley, and Gene Titmus. The popularity of this event grew over the next few years and eventually it moved to Letchworth State Park where it is still held annually, generally the last weekend in August.

With Jack's increased involvement in archaeology and interest in lithic sources came his realization that most archaeologists did not know the sources of the lithic material found on their sites. Furthermore, there was no major repository of lithic material in North America where one could compare a lithic specimen to known sources. When Jack visited the few institutions said to have lithic study collections, what he generally found were small, regional collections or collections of stone tools that were said to be made of specific cherts. If raw material had been collected from the source, the range of variability in the material was rarely represented. Jack decided that a comprehensive North American comparative lithic collection was needed. Thus he embarked on his second career: chert chaser.

Jack would visit the geologic outcrop, taking multiple samples from different accessible areas, recording the location of the specimens collected. This activity took him to all 50 states and he amassed over 22,000 samples representing more than 1,500 named lithic types from the United States and Canada. Early on, Kevin Smith, then at the Buffalo Museum of Science, saw the value of these efforts. Through Kevin Smith's efforts, the collection was housed in the Holland Lithic Laboratory of the Buffalo Museum of Science and Jack became a Research Fellow of the Museum. Jack assisted many archaeologists in the identification of the probable source of the samples they brought or sent to the Lithic Lab. In doing so, he relied on his encyclopaedic memory to check samples against those in the collection. Jack generally did this for no charge, happy to share his knowledge. He also loaned or gave samples to both contract firms and academic departments for their use in sourcing materials. He also assisted many individuals (including the senior author) and CRM firms with lithic analysis.

As part of his research, Jack started systematically going through the geological and archaeological literature for selected regions and found terminological chaos. Archaeologists and geologists frequently used different terms for the same source and some outcrops had multiple names. Jack therefore started a reference bibliography with folders for every lithic source. Over the years, Jack began to produce a number of highly useful reference works for different states, listing the lithic sources for each state along with the alternative names for each source and the bibliographic references for that source. Some of this information remains unpublished, but is preserved in folders associated with the lithic collection.

The importance of Jack's work was recognized by awards from the Society for Pennsylvania Archaeology and the New York State Archaeological Association. In 2001 he received the Crabtree Award from the Society for American Archaeology and in 2008 he was named a Pioneer of Science by the Hauptman-Woodward Institute of Buffalo, the latter honour resulting in a large photograph of Jack being hung in the Buffalo-Niagara International Airport for a year. During the last five years of his life, declining health prevented Jack from continuing his research, though he regularly attended meetings of the Houghton Chapter of the New York State Archaeological Association. In the last year of his life he got rides from his nursing home to go to meetings. Through the efforts of Dennis Stanford, the Holland Lithic Collection and associated documentation was transferred to the Smithsonian Institution where it will serve as a lasting legacy of Jack Holland's contribution to archaeology and geology. 


\section{Bibliography}

\section{Sole Author}

Holland, J. D., 1988, Some Dover Billets. In Twentieth Century Lithics, (Waldorf, D.C., Ed.), Mound Builder Books, Branson, Missouri, p. 93-96.

Holland, J. D., 1989, Paleoindian Conference in Maine. Chips, A Publication of the Flintknappers' Guild International. 1(3): 3.

Holland, J. D., 1991, Review of Arrowheads and Spear Points of the Prehistoric Southeast: A Guide to Understanding Cultural Artifacts, by Linda Crawford, University Press of Mississipppi, Jackson. Journal of World Anthropology 1(1).

Holland, J. D., 1992, Onondaga Chert. Chips, A Publication of the Flintknappers' Guild International. 4(1): 3-5.

Holland, J. D., 1992, Silver Mound Quartzite: or is it? Chips, A Publication of the Flintknappers' Guild International. 4(2): 3-4.

Holland, J. D., 1992, Burlington Chert. Chips, A Publication of the Flintknappers' Guild International. 4(3): 3-4.

Holland, J. D., 1992, Knife River Flint. Chips, A Publication of the Flintknappers' Guild International. 4(4): 4-5.

Holland, J. D., 1993, Glass of the Fire Mountains. Chips, A Publication of the Flintknappers' Guild International. 5(2): 6-7.

Holland, J. D., 1993, The ABC's of Flintknapping: A Flintknappers' Alphabet. Bulletin of Primitive Technology. Society of Primitive Technology. 5: 71-72.

Holland, J. D., 1993, Paleoindians of Western New York. In Prehistory of Western New York, (Herold, E., Ed.), State University of New York at Buffalo and F. M. Houghton Chapter, New York State Archaeological Association. p. 10-14.

Holland, J. D., 1994, English flint on the Coast of Maine. Chips, A Publication of the Flintknappers' Guild International. 5(2): 6-7.

Holland, J. D., 1994, Lithic Procurement at the Paleo Crossing Site, Medina County, Ohio. Current Research in the Pleistocene. 11: 61-63.

Holland, J. D., 1994, Mount Jasper Rhyolite. The Flintknappers' Exchange. Baton Rouge.

Holland, J. D., 1996, Geoarchaeology of the Kilmer Site: A Paleoindian habitation site in the Appalachian Uplands. North American Archaeologist. 17: 93-111.

Holland, J. D., 1999, Lamb Site Lithics: Local and Exotic - An Analytical Assessment. American Society for Amateur Archaeology. 5: 103-104.

Holland, J. D., 2003, A Guide to Pennsylvania Lithic Types. Journal of Middle Atlantic Archeology.19: 129-150.

Holland, J. D., 2004, New Data on late-Pleistocene Lithic Artifacts from the Hiscock Site (Western New York). Current Research in the Pleistocene. 21: 46-48.

Holland, J. D., 2004, Lithic Types of New York. The Bulletin: Journal of the New York State Archaeological Association. 120: 17-36.

Holland, J. D., 2005, Chert and Other Lithic Materials of Prehistoric New Jersey. Bulletin of the Archaeology Society of New Jersey. 60: 54-61. 
Holland, J. D., 2005, Types and Varieties of Archaeologically Relevant Ohio Chert. Ohio Archaeologist. 55: 20-22.

Holland, J. D., 2006, Virginia Lithic Types: Chert, Quartzite, and Others. The Quarterly Bulletin of the Archaeological Society of Virginia. 61: 137-152.

Holland, J. D., 2007, West Virginia Lithics of Potential Prehistorical Significance. West Virginia Archeologist. 53: 19-24.

Holland, J. D., 2008, Illinois Chert Types. Illinois Antiquity. 43: 3-17.

Holland, J. D., 2009, FDR and me: archeology-politics. Bulletin of the Buffalo Society of Natural Sciences. 38: 31-32.

\section{Co-Authored publications}

Tankersley, K. B. \& Holland, J.D., 1994, Lithic Procurement Patterns at the Paleo Crossing site, Medina County, OH. Current Research in the Pleistocene. 11: 61-63.

Ennis, R., Hess, M., Holland J.D., Honsinger, V., Smith, K. P., Tankersley, K.B., \& Vanderlaan, S., 1995, Survey and Test Excavations at the Arc site, Genesee County, New York. Current Research in the Pleistocene. 12: 9-11.

Tankersley, K.B., Holland, J.D., \& Kilmer, R.L., 1995, The Kilmer Site: A Paleoindian Site in the Allegheny Plateau. Current Research in the Pleistocene. 12: 46-48.

Tankersley, K.B., Holland, J.D., \& Kilmer, R.L., 1996, Geochronology of the Kilmer Site: A Paleoindian Habitation in the Appalachian Uplands. North American Archaeologist. 17(2): 93-111.

Tankersley, K.B., Vanderlaan, S., Holland, J.D., \& Bland, S., 1997, Geochronology of the Arc Site: A Palaeoindian Habitation in the Great Lakes Region. Archaeology of Eastern North America. 25: 31-44

Smith, K.P., O'Donnell, N., \& Holland, J.D., 1998, The Early and Middle Archaic in the Niagara Frontier: documenting the "Missing Years" in Lower Great Lakes Prehistory. In Contributions to the Natural Sciences and Anthropology: a Festschrift in Honor of George F. Goodyear, convened by Ernst E. Both. Bulletin of the Buffalo Society of Natural Sciences. 36: 1-79.

Holland, J.D., \& Ashton, R.L., 1999, The Flately Brook Quarry: A source of Normanskill Chert Located in Washington County, New York. The Bulletin: Journal of the New York State Archaeological Association. 115: 13-16.

Ellis, C.J., Tomenchuk, J., \& Holland, J.D., 2003, Typology, Use and Sourcing of the Late Pleistocene Lithic Artifacts from the Hiscock Site. In The Hiscock Site: Later Pleistocene and Early Holocene Paleoecology and Archaeology of Western New York State (Laub, R.S., Ed.), Bulletin of the Buffalo Society of Natural Sciences Vol. 37. Buffalo Society of Natural Sciences, Buffalo: p. 221-237.

Storck, P.L., \& Holland, J.D., 2003, From Text to Context: Hiscock in the Paleoindian World. In The Hiscock Site: Later Pleistocene and Early Holocene Paleoecology and Archaeology of Western New York State, (Laub, R.S., Ed.), Bulletin of the Buffalo Society of Natural Sciences Vol. 37., Buffalo Society of Natural Sciences, Buffalo: p. 281-300.

Holland, J.D., \& Ashton, W., 2008, Indiana Chert Types. Illinois Antiquity. 43: 18-26. 
Smith, K.P., Engelbrecht, W. \& Holland, J.D., 2010, Late-Paleoindian Archaeology at the Eaton Site, Western New York. Current Research in the Pleistocene. 27: 142-145.

Roets, M., Engelbrecht, W. \& Holland, J.D., 2014, Gunflints and Musket Balls: Implications of the Occupational History of the Eaton Site and the Niagara Frontier. Northeast Historical Archaeology. 43: 18-33.

\section{Reports}

Holland, J.D., 1992, R. Haas Site II (UB 1061), Orchard Park, NY: Artifact assemblage \& lithic analysis. Prepared for R. M. Braun, Watch Hill Development Corp., Orchard Park, New York. Smithsonian National Anthropological Archives.

Holland, J.D., 1992, Selected Lithic Sources of Public Accessible Sites. Smithsonian National Anthropological Archives.

Holland, J.D., 1993, Lithic Sources of the Northeast. Smithsonian National Anthropological Archives.

Holland, J.D., 1993, McKee Site (Bear Paw), Niagara County, New York. Lithic Analysis, Stage 3, Locus 2, Test Units. Smithsonian National Anthropological Archives.

Holland, J.D., 1994, Arc Site (MDA 17-4) Genesee County, New York, Artifact Inventory: Stanley Vanderlaan Collection. Holland Lithic Laboratory, Buffalo Museum of Science, Buffalo, New York. Smithsonian National Anthropological Archives.

Smith, D., Schieppati, F., Holland, J.D., Emans, R., Steinbeck, M., \& Cinquino, M., 2007, Phase III Cultural Resources Investigation of the Prehistoric Component (AO.0236502940) within the Erie Canal Harbor Archaeological District, City of Buffalo, Erie County, New York. Smithsonian National Anthropological Archives. 